Original Research Paper

\title{
Effects of Root Rot in Soybean Cultivars with Diverse Susceptibility to the Disease on Plant Physiology, Yield, Amino Acids and Mycotoxins Profile in Climatic Conditions of Kazakhstan
}

\author{
${ }^{1}$ Nurlan Kuldybayev, ${ }^{1}$ Yerlan Dutbayev, ${ }^{2}$ Bozena Lozowicka, ${ }^{2}$ Piotr Iwaniuk, \\ ${ }^{1}$ Ayana Slyamova and ${ }^{3}$ Vladimir Tsygankov \\ ${ }^{1}$ Kazakh National Agrarian Research University, Almaty, Kazakhstan \\ ${ }^{2}$ Plant Protection Institute - National Research Institute, Poznan, Poland \\ ${ }^{3}$ Aktobe Agricultural Experimental Station, Aktobe, Kazakhstan
}

Article history

Received: 09-06-2021

Revised: 29-07-2021

Accepted: 03-08-2021

Corresponding Author:

Yerlan Dutbayev

Kazakh National Agrarian

Research University, Almaty,

Kazakhstan

Email: edutbaev@mail.ru

\begin{abstract}
Soybean is an important high-value crop but susceptible to soil-borne diseases. A field trial was conducted in Kazakhstan to evaluate the effects of soybean cultivars and Fusarium root rot severity on soybean crop physiology, chlorophyll fractions and amino acids profile. The highest yield was achieved in 2018 (up to $4 \mathrm{t} \mathrm{ha}^{-1}$ ) for K-9648 cultivar. The greatest root rot severity $(90 \%)$ and the lowest plant high $(20.8 \mathrm{~cm})$, number of beans per plant (54) were determined in 2020 and were related with the highest precipitations. Moreover, leaf position was crucial in determination of chlorophyll fractions, among which the highest values were achieved in $4^{\text {rd }}$ leaf. Average concentration of non-essential, essential, aromatic and aliphatic amino acids were correlated with root rot development at flowering $(\mathrm{r}=0.73)$ and maturing stage $(\mathrm{r}=0.54)$, root rot severity $(\mathrm{r}=0.64)$ and precipitations $(\mathrm{r}=0.86)$. Thus, amino acids play the crucial role in defense proteins biosynthesis against biotic stress factors. Interestingly, despite Fusarium root rot occurrence, there were not determined mycotoxins in seeds, which indicate that they are not distributed to other organs from the place of their biosynthesis. This study indicated that among twelve soybean cultivars, Tanais and Isidor cultivars are at least susceptible to Fusarium root rot despite heavier rainfalls in 2020 and in this regard could be implemented to agriculture in the agro climatic conditions of Kazakhstan. However, in aspect of yield and desired amino acids profile, K-9648 cultivar was the most productive in 2018-2020.
\end{abstract}

Keywords: Amino Acids, Multispeq, Plant Physiology, Root Rot, Soybean

\section{Introduction}

Soybean is one of the most important agronomic crops drawing greater attention worldwide due to increasing demand on its products (e.g., oil, soy milk, soy protein, lecithin, tofu or soy sauce). Moreover, soybean is a rich source of protein and therefore is used as a feed in animal nutrition. Total Amino Acids (AA) content in soybean is up to $42 \%$ of dry mass (Assefa et al., 2018), far more than any other plant from legumes. However, its content may be diverse depending on cultivar, climatic conditions and fungal disease development. Soybean is susceptible to various diseases, mainly from fungal ones (Fones et al., 2017; Kalaitzandonakes et al., 2019; Li et al., 2019). Common fungal diseases are sudden death syndrome, damping-off and root rot, which are caused by Fusarium oxysporum (Cruz Jimenez et al., 2018; Chang et al., 2018; McLaren and Callahan. 2020), F. equiseti (Kuldybayev et al., 2019; You and Barbetti, 2017), F. virguliforme (Wang et al., 2019) under certain environmental conditions. Soil-borne diseases contribute to the decrease of roots length and weight, length of plant, weaken general plant condition and in consequence contribute to lower yield (Dutbayev et al., 2020c). Infections caused by Fusarium spp. can impact on photosynthesis (Dutbayev et al., 2020a) and therefore, understanding how soybean cultivars impact on photosynthetic properties is critical to develop management practices sustaining healthy and high-yield soybean (Abdulmajeed and Qaderi, 2019; Becklin et al., 2016; Nelson et al., 2018). Another negative effect of 
Fusarium root rot is mycotoxins secretion and contamination of soy-originated food and feed. Main mycotoxins determined in soybean are fumonisins, aflatoxins, deoxynivalenol (Gutleb et al., 2015).

Basic procedure preventing fungi development is fungicides application. However, in conjunction with worldwide tendency to limiting pesticides usage, ecological methods of cultivation are gaining in importance. Additionally, there were also implemented biological methods of protection, e.g., based on Trichoderma isolates, which inhibit Fusarium virguliforme growth, reduce root rot and induce defense-related genes in soybean seedlings (Pimentel et al., 2020) However, one of the milestones of effective, pesticides-free tillage is appropriate selection of soybean cultivars resistant to diseases in particular climatic conditions(Raza, 2019; Nyandoro et al., 2019; Sjarpe et al., 2020; Abdukadirova et al., 2016; Abugalieva et al., 2016).

Plant phenotyping is becoming increasingly important in plant biology and agriculture, however, the application of this approach is limited by long-term analytical techniques and processing of the results (Kuhlgert et al., 2016). One of the direction of non-disrupting analytical techniques is MultispeQ device designed for large-scale collection of high-quality plant health data and non-invasive evaluation of plant physiological conditions (Kuldybayev et al., 2019, 2020; Dutbayev et al., 2020b, 2020c; Zatybekov et al., 2018). It can be simply use for the determination of soybean cultivars photosynthetic status in the response to root rot. MultispeQ is dedicated for the evaluation of LEF (linear electron flow - the determinant of the electron transfers order), NPQt (non-photochemical quenching - chlorophyll protection system from the adverse effect of high light intensity), PSII (Photosystem II - the fraction of light energy captured by Photosystem II which is directed towards Photochemistry to make ATP and NADPH), Photo Synthetically Active Radiation (PAR).

Taking under consideration facts above, the objective of our study was to evaluate the influence of root rot in twelve soybean cultivars with diverse susceptibility to the disease on plant physiology, yield, amino acids and mycotoxins profile in changing climatic condition of Kazakhstan.

\section{Materials and Methods}

\section{Experimental Design}

A field study in completely randomized design was conducted on twelve soybean cultivars with different susceptibility to Fusarium root rot. Seeds were sown in triplicate, on May $20^{\text {th }}-24^{\text {th }}, 2018-2020$ in the Aktobe Agricultural Experimental Station (Aktobe, Kazakhstan; $50^{\circ} 16^{\prime} 0^{\prime \prime} \mathrm{N}, 57^{\circ} 13^{\prime} 0^{\prime \prime} \mathrm{E}$ ). The dimensions of each plot were $6 \times 2 \mathrm{~m}$, with an inter-plot strip $30 \mathrm{~cm}$ wide. The soil of the experimental field was dark chestnut, medium loamy in texture. The humus content in the upper soil layer $(0-20 \mathrm{~cm})$ was $2.74 \%$. The soybean cultivation was not fertilized and any chemical protection was applied. Soybean was harvested manually on September $7^{\text {th }}-18^{\text {th }}$, 2018-2020. Temperature and precipitation data of the vegetative season are presented in Fig. 1.

\section{Root Rot, Yield and Plant Physiology Assessment}

Root rot development in soybean was determined at the flowering and maturing stage, visually from 25 randomly collected plants, according to the formula:

$$
R=a b \times 100 / A K
$$

where: "a" is the number of plants with the same damage; " $b$ " is the corresponding lesion score; " $A$ " is the number of plants in the count; " $\mathrm{K}$ " is the highest score of defeat. Root rot severity in 25 plants of each repetition was evaluated visually, in three-point scale (healthy $<10 \%$, low 10-20\%, moderate and high $>20 \%$ ) according to EPPO (European and Mediterranean Plant Protection Organization) recommendations.

Plant height (length from the root neck to the tip of the central stem, cm), height of the lower bean (length from the root neck to the attachment point of the lowest bean, $\mathrm{cm}$ ) was determined using tape measure, while the number of beans per plant, weight of 1000 beans $(\mathrm{g})$ and yield $\left(\mathrm{t} \mathrm{ha}^{-1}\right)$ was evaluated using seed meter (Arlab, Koszalin, Poland).

\section{Photosynthetic Parameters Determination}

Measurements of photosynthetic parameters were conducted on randomly collected plants $(n=25)$ from each plot at flowering and maturing growth stages, using Multispeq 1.0 device. It was equipped with a relative humidity, temperature and $\mathrm{CO}_{2}$ sensor. The following parameters were examined: LEF (linear electron flow - the determinant of the electron transfer order), NPQt (non-photochemical quenching - chlorophyll protection system from the adverse effect of high light intensity), PSII (Photosystem II - the fraction of light energy captured by Photosystem II which is directed towards Photochemistry to make ATP and NADPH), PAR (photosynthetically active radiation) and relative chlorophyll content according to Kuhlgert et al. (2016).

\section{Amino Acids Determination}

Amino acids standards: Alanine, arginine, asparagine, aspartic acid, cysteine, glutamic acid, glutamine, glycine, histidine, isoleucine, leucine, lysine, methionine, phenylalanine, proline, serine, threonine, tryptophan, tyrosine, valine were obtained from Sigma-Aldrich (St. Louis, USA). Individual stock solutions were prepared in $1 \%$ formic acid in water at a concentration of $1 \mathrm{mg} \mathrm{mL}^{-1}$. Standard mixture was prepared at the concentrations 0.01-10 $\mu \mathrm{g} \mathrm{mL}^{-1}$ and was stored at $4^{\circ} \mathrm{C}$.

Soybean was milled in the laboratory mill, weighted (1 g) and mixed with $10 \mathrm{~mL}$ of water-methanol solution 
$(8: 2, \mathrm{v} / \mathrm{v})$ with $0.1 \%$ formic acid. Samples were vortexed for $5 \mathrm{~min}$ and centrifuged for $10 \mathrm{~min}$ at $10000 \mathrm{rpm}$. Extracts ( $1 \mathrm{~mL}$ ) were filtered through a $0.22 \mu \mathrm{m}$ hydrophilic PTFE filter, transferred into the vial and analyzed via LC-MS/MS followed by the validation according to the Document No. SANTE/11813/2017 (EC, 2017).

An Eksigent Ultra LC-100 (Eksigent Technologies, Dublin, CA, USA) liquid chromatography system was used (flow rate $0.5 \mathrm{~mL} \mathrm{~min}^{-1}$ ) with KINETEX HILIC $1.7 \mu \mathrm{m}, 2.1 \times 50 \mathrm{~mm}$ (Phenomenex) column, kept at $40^{\circ} \mathrm{C}$ during analysis. The purified extract $(2 \mu \mathrm{L})$ was injected into the LC-MS/MS. The mobile phases consisted of water $+0.2 \%$ formic acid $+20 \mathrm{mM}$ ammonium formate (phase A) and acetonitrile (phase B). The experiment started at $5 \% \mathrm{~A} / 95 \% \mathrm{~B}$ for $1 \mathrm{~min}$, raised to $10 \% \mathrm{~A} / 90 \% \mathrm{~B}$ in 2 min., then to $95 \% \mathrm{~A} / 5 \% \mathrm{~B}$ in $3.5 \mathrm{~min}$ and was held for $1.5 \mathrm{~min}$. Next, the mobile phase components were restored to the initial conditions and were held for $3 \mathrm{~min}$. System MS/MS 6500 QTRAP (AB Sciex Instruments, Foster City, CA) was operated for mass spectrometric analysis, equipped with an Electrospray Ionization Source (ESI). The capillary voltage was maintained at $4000 \mathrm{~V}$ for positive ion. The temperature of the turbo heaters was set at $400^{\circ} \mathrm{C}$. Nitrogen was used as nebulizer Gas (GS1), auxiliary Gas (GS2) and Curtain gas (CUR) at a pressure of 50, 60 and $40 \mathrm{psi}$, respectively. Nitrogen was also used as the nebulizer and collision gas. All amino acids were detected in the Multiple Reaction Monitoring mode (MRM).

\section{Mycotoxins Determination}

Mycotoxins: Deoxynivalenol (DON) and its acetylated forms (3-AcDON, 15-AcDON), Nivalenol (NIV), Zearalenone (ZON), Diacetoxyscirpenol (DAS) Fusarenon X (FusX), T-2, HT-2 and Fumonisins (Fum B1, Fum B2, Fum B3), Neosolaniol (NEO) were obtained from LGC (Wasel, Germany). Individual stock solutions were prepared in acetonitrile/water $(1: 1, \mathrm{v} / \mathrm{v})$ at a concentration of $1 \mathrm{mg} \mathrm{mL}^{-1}$ and were used to obtain a standard mixture at the $0.1-1000 \mu \mathrm{gmL}^{-1}$ concentrations. The standard mixture was stored at $-18^{\circ} \mathrm{C}$.

Mycotoxins were extracted using QuEChERS method and analyzed via LC-MS/MS based on Nugmanov et al. (2018 protocol), followed by the validation according to the Document No. SANTE/11813/2017 (EC, 2017).

\section{Statistical Analysis}

Data statistical processing was performed using the Statistica 12.0 program. Analysis of Variance (ANOVA) was conducted and Pearson's correlation coefficients were indicated based on Principal Component Analysis (PCA). The statistical significance was established as $\mathrm{p} \leq 0.05$.

\section{Results}

\section{Climatic Conditions and Root Rot Development}

Aktobe region is located almost in the center of the Eurasian continent. This determines the features of a sharply expressed continental climate with high continentality, which increases from the northwest to the southeast. In the summer, dry overheated tropical air masses are removed from the south to the region from the deserts of Central Asia and Iran and from the north - northern, arctic air masses from beyond the Urals. The average temperatures in vegetative seasons were $20.2,21.0,21.2^{\circ} \mathrm{C}$, while precipitations were 19.5, 15.1, $31.1 \mathrm{~mm}$ in 2018-2020, respectively (Fig. 1). Our results indicated the year climatic conditions more impacted on soybean root rot index than cultivar dependent resistance. The development of soybean root rot was observed from seedling stage. The analysis of general distribution of root rot severity during plant flowering showed diversified values between $2018-2019(10.8-30.3,25-56 \%$, respectively) and $2020(6.9-12.5 \%)$. Meanwhile, during soybean maturing the root rot development was significantly higher in 2018 and 2020 (19.4-50.5\%) but lower in 2019 (35.2-60.5\%) (Fig. 2).

\section{Crop Physiology}

Results of the study indicated the highest yield in 2018 (up to $4 \mathrm{t}$ ha-1), which was correlated with climatic conditions, root rot severity and development. In three-year study, generally the greatest soybean yield was determined in healthy plants and gradually decreased achieving the lowest values in plants with middle and high root rot severity (up to 1.4 t ha-1 in 2020 for Cheremosh cultivar). Low level of root rot caused yield loses up to $5.4 \%$, while for middle and high level yield losses varied between 12.1-38.7\% (Table 1). In 2018-2020 the highest weight of 1000 beans was determined in Cheremosh, Tanais and Samer 5 soybean cultivars, with 121.9-278 g losses from Fusarium root rot between 79.4 and $105.6 \mathrm{~g}$ for each 1000 beans. The average weight of 1000 beans was the lowest in Anastasya, Samer 1, Samer 3 and Swapa cultivars (95.6-167.3 g) with losses caused by root rot 11-60.7 g per each 1000 beans. These indexes at Belor, Isidor, Maple Ridge and Samer 2 were 115.3-195.4 g with losses 33.9-82.7 g. There were observed significant higher differences in root rot development in maturing stage (up to $60.5 \%$ in 2019) (Fig. 2).

Root rot severity was significantly correlated with precipitation $(\mathrm{r}=0.61)$, sum of free amino acids $(\mathrm{r}=0.61)$ and root rot development at flowering stage $(r=0.67)$ (Table 2 and Fig. 3) and impacted on reduced plant height (up to $21.6 \mathrm{~cm}$ ), number of beans per plant (up to 8.2), weight of 1000 beans (up to $92.5 \mathrm{~g}$ ) and yield but contributed to the increase of lower bean height (up to $13.2 \mathrm{~cm}$ ) (Table 1).

\section{Photosynthetic Properties}

In 2018-2020, leaf position impacted to chlorophyll fractions, LEF and PAR. It was determined higher values of PhiNPQ (0.34), NPQt (1.2) and LEF (174) in $4^{\text {th }}$ leaf, 
while PAR reached greater values in $3^{\text {rd }}(48)$. The general distribution of these variables was in normal range, thus ANOVA was used $(\mathrm{p}<0.001)$. Interaction of root rot and genotypes significantly impacted to Phi2 chlorophyll fractions numerical variables. There were not observed significant differences of PhiNPQ, NPQt, LEF, PAR chlorophyll fractions between soybean cultivars. The impact of soybean leaf position on photosynthetic parameters in 2018-2020 is given in the Table 3.

\section{Amino Acid and Mycotoxin Profile of Soybean Cultivars}

Among analyzed soybean cultivars the greatest value of the sum of Free Amino Acids (FAA) was obtained in K-9648 cultivar $\left(5024.2 \mu \mathrm{g} \mathrm{kg}^{-1}\right)$. Most of cultivars had high values of the sum of FAA (above $1000 \mu \mathrm{g} \mathrm{kg}^{-1}$ ), except Cheremosh (725.8 $\left.\mu \mathrm{g} \mathrm{kg}^{-1}\right)$ and Samer $2\left(862.5 \mu \mathrm{g} \mathrm{kg}^{-1}\right)$. Moreover, among tested cultivars, K-9648 was the most abundant in non-essential, essential and aliphatic FAA (2684.6, 2339.6 and $468.7 \mu \mathrm{g} \mathrm{kg}^{-1}$, respectively). However, Samer 1 cultivar had the highest value of aromatic FAA $\left(956 \mu \mathrm{g} \mathrm{kg}^{-1}\right)$ (Fig. 4). All groups of FAA were positively correlated with temperature $(\mathrm{r}=0.53)$, precipitation $(\mathrm{r}=0.86)$, root rot development $(r=0.77)$ and severity $(r=0.64)$ (Table 2$)$.

Despite diversified level of root rot development, the level of following mycotoxins: DON, 3-AcDON, 15AcDON, NIV, ZON, DAS, FusX, T-2, HT-2, FumB1, FumB2, FumB3, NEO was under LOD (limit of detection, $<0.001 \mu \mathrm{g} \mathrm{kg}^{-1}$ ) in soybean samples.

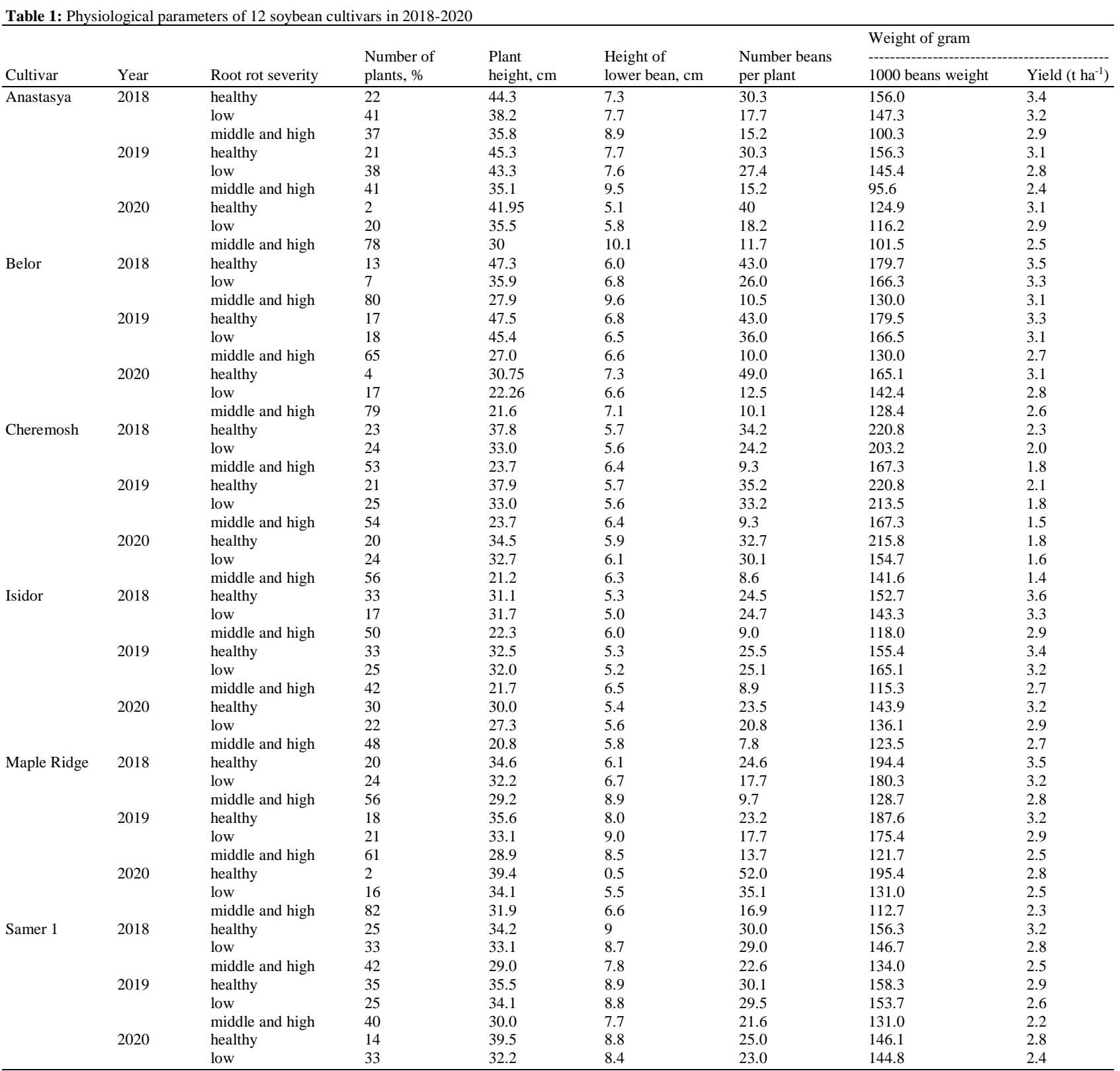


Nurlan Kuldybayev et al. / OnLine Journal of Biological Sciences 2021, 21 (4): 312.321 DOI: 10.3844/ojbsci.2021.312.321

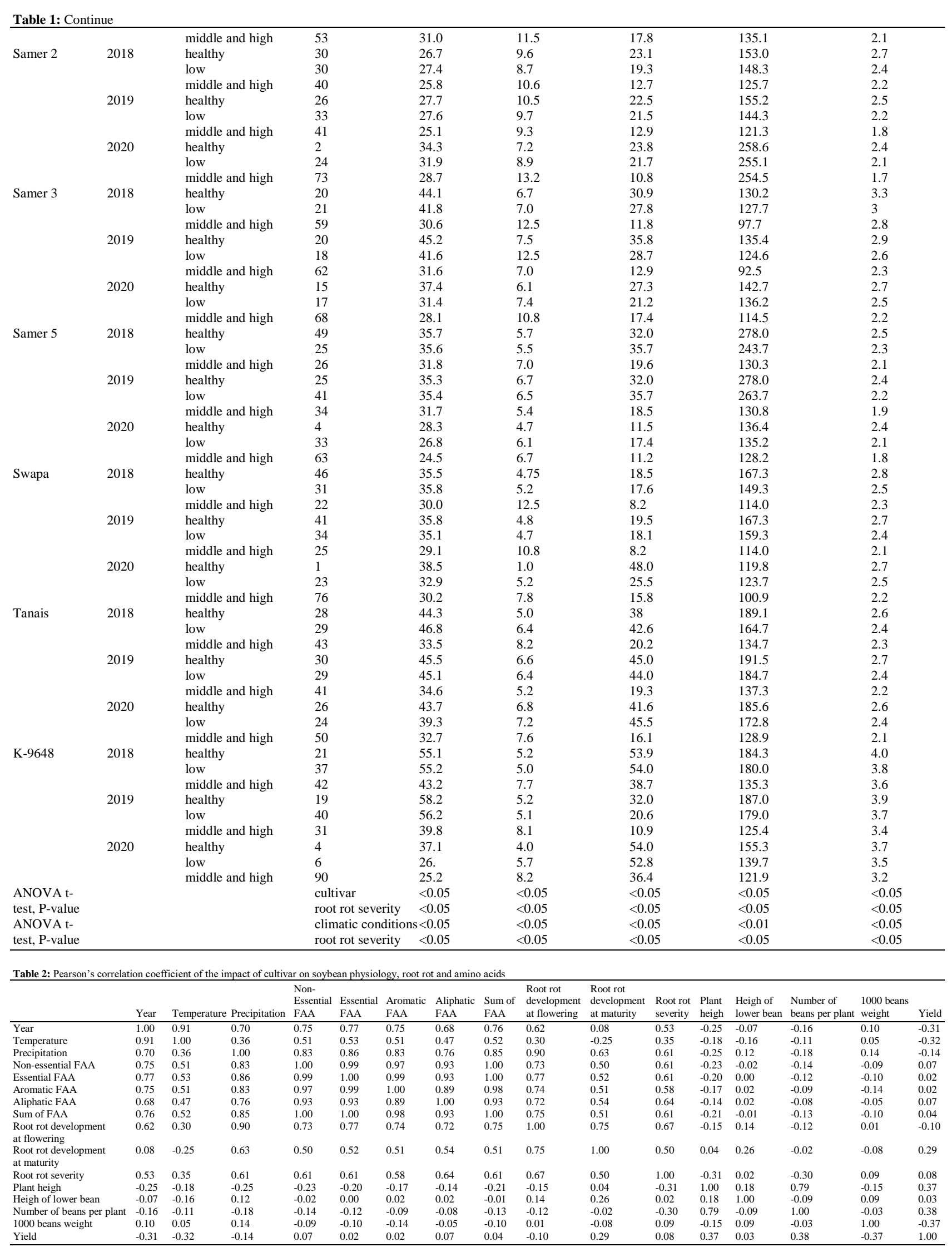


Table 3: Average chlorophyll fractions in soybean depending on leaf position in 2018-2020 ( $\mathrm{p} \leq 0.05)$

\begin{tabular}{llll}
\hline & Chlorophyll fractions & Leaf position & $\mu \mathrm{M}$ of photons $\mathrm{m}^{-2} \mathrm{~s}^{-1}$ \\
\hline & PhiNPQ & $3^{\text {rd }}$ leaf & 0.25 \\
p-value & & $4^{\text {th }}$ leaf & 0.34 \\
& & & 0.023 \\
p-value & NPQt & $3^{\text {rd }}$ leaf & 0.7 \\
& & $4^{\text {th }}$ leaf & 1.2 \\
p-value & LEF & $3^{\text {rd }}$ leaf & 0.033 \\
& & $4^{\text {th }}$ leaf & 120 \\
& PAR & $3^{\text {rd }}$ leaf & 174 \\
p-value & & $4^{\text {th }}$ leaf & 0.012 \\
\hline
\end{tabular}

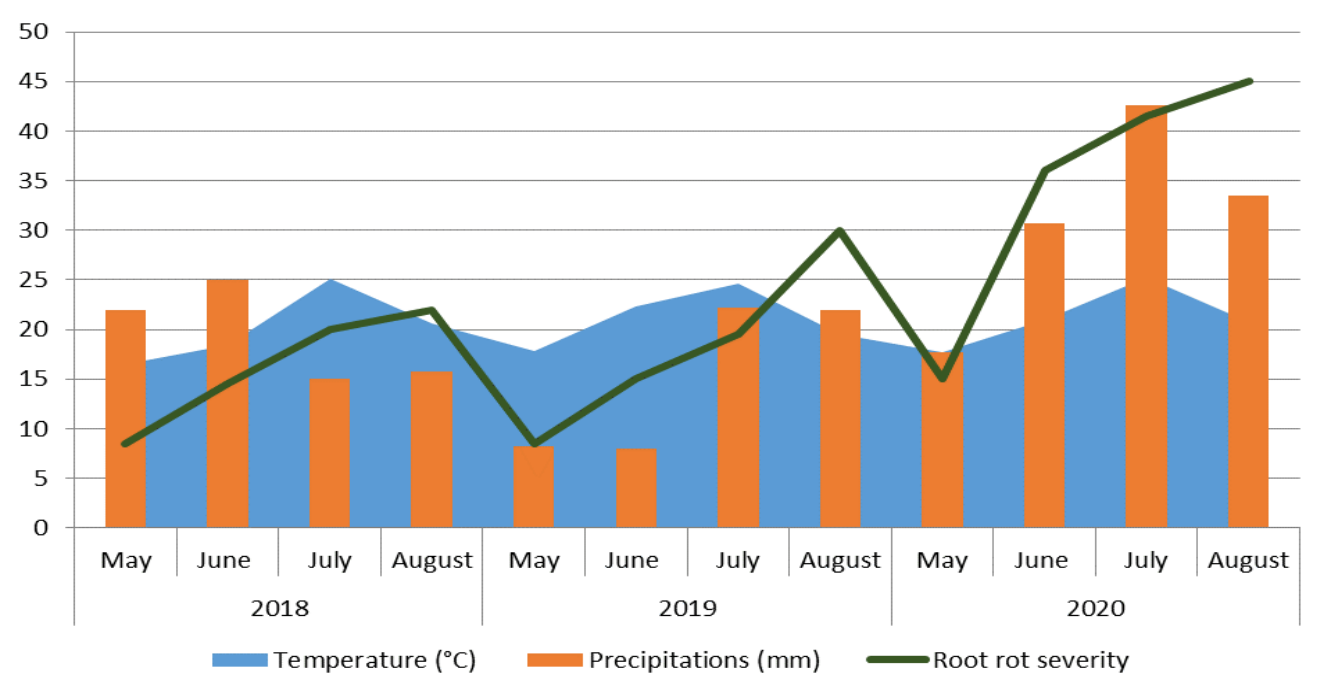

Fig. 1: Temperature, precipitations and root rot severity in soybean, in 2018-2020

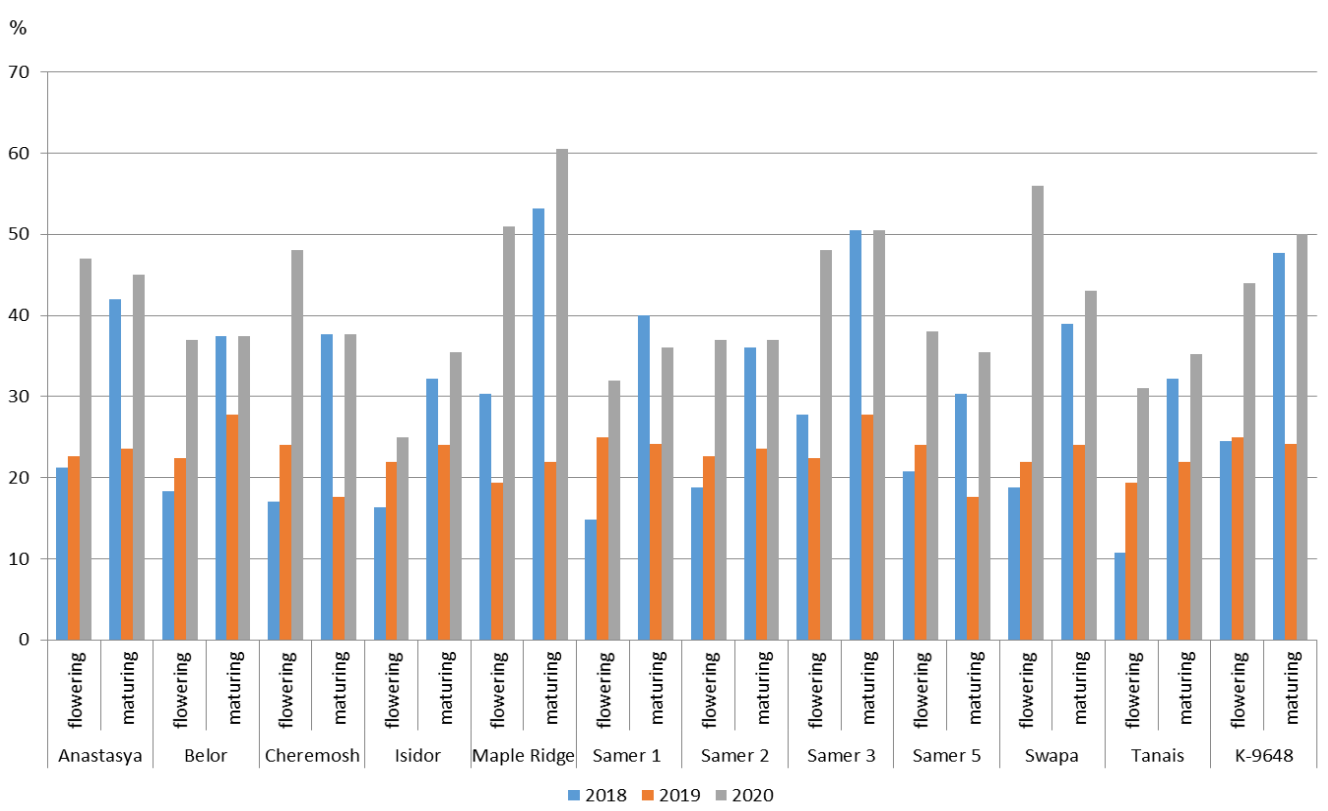

Fig. 2: Fusarium root rot development in flowering and maturing stages, in 2018-2020 


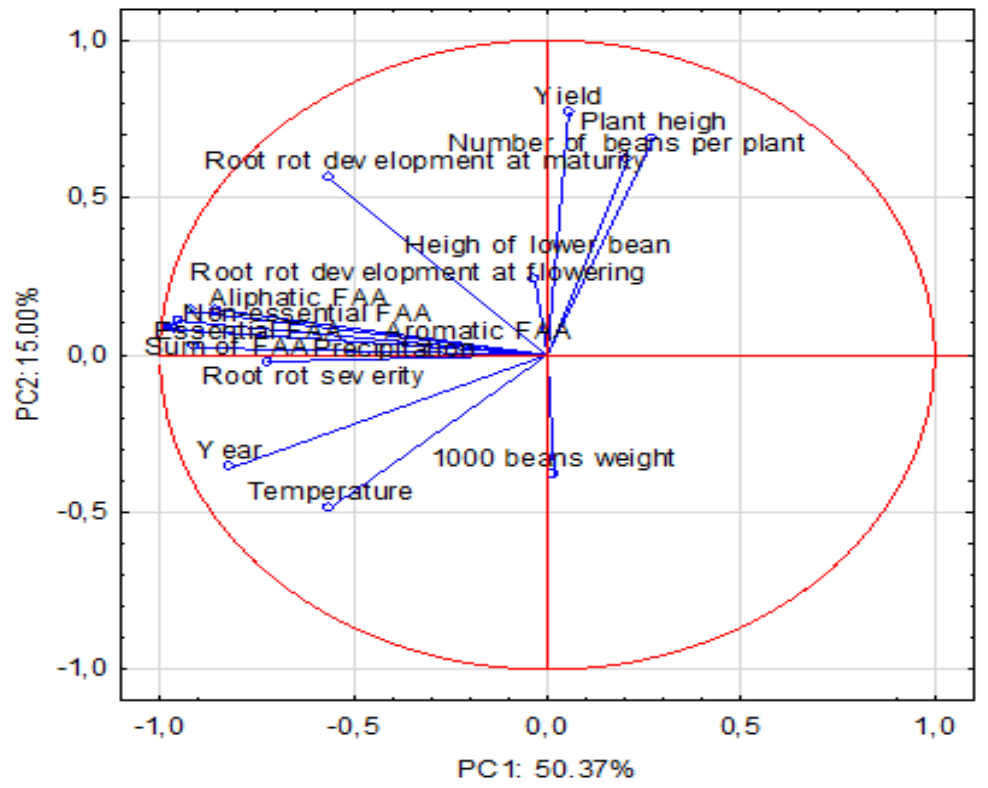

Fig. 3: Principal component analysis of the impact of cultivar on soybean physiology, root rot and free amino acids

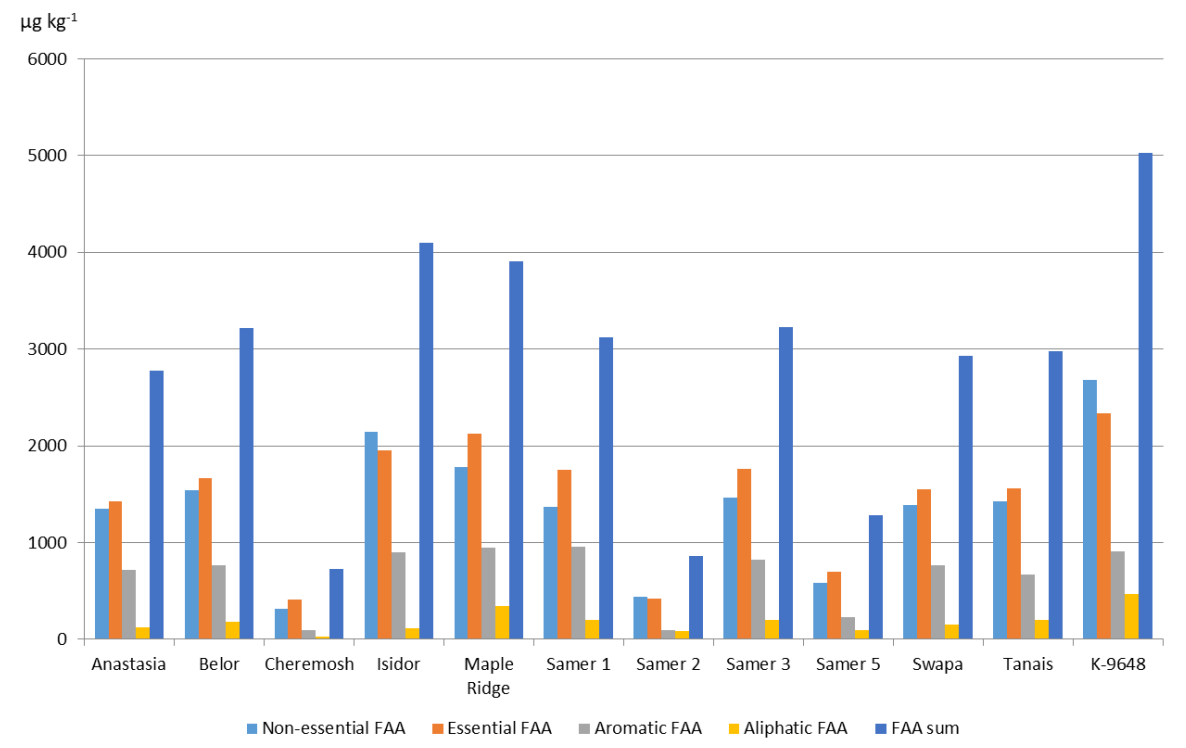

Fig. 4: Amino acids concentration in soybean cultivars (average values from 2018-2020)

\section{Discussion}

Assessment of yield is very important for drawing up strategies for combating various plant diseases Our results determined that cultivar susceptibility to Fusarium root rot is diverse what allows indication of most resistance cultivars in climatic conditions of Kazakhstan. There were noticed soybean yield losses up to $68 \%$ as a result of soybean cultivars inoculation by the Rhizoctonia solani (Chang et al., 2017). In this study soybean yield losses due to Fusarium root rot varied from 30 to $53.2 \%$, depending on the cultivar. Moreover, our study revealed gradual reduction of 1000 beans weight, plant high and number of beans per plant which was also confirmed by Zhang et al. (2010). However, in contrast to Cruz Jimenez et al. (2018), root rot development and severity was more dependent from greater precipitations that temperature.

The process of photosynthesis as the basis for the productivity of any culture can be influenced not only by abiotic factors but also biotic ones (Kuldybayev et al., 
2019; Passari et al., 2019; Aphalo, 2017; Bauriegel et al., 2011). These pathogens, mainly soil-borne cause root rot of plants (Chang et al., 2020). Metabolites of fungal pathogens cause carbon starvation by suppressing photosynthesis (Xing et al., 2020). Among the physiological indicators, chlorophyll a fluorescence is the most valuable parameter of photosynthesis (Kalaji et al., 2017), which provides information on the efficiency of Photosystem II and I as components of the light harvesting complex under environmental stress (Olšovská, 2001). This parameter can inform about the nature of the disease and the level of resistance or susceptibility of plants to a certain strain of the fungus already in the first days of infection (Matorin et al., 2018; Chilvers, 2019). Protective mechanisms of the photosynthetic apparatus have special properties. One of them is NPQt or nonphotochemical quenching which opposes excess light (Critchley, 1998) and act as a safe mechanism for dissipating significant levels of excitation energy of chlorophyll (Murchie and Lawson, 2013). Previously it was noticed that soybean cultivar has a significant effect on the Linear-Electron Flow (LEF) after F. equiseti inoculation (Kuldybayev et al., 2020). According to the statistical analysis, the results can be explained possibly by the presence of metabolic products in plants affected by the pathogen. Lack of mycotoxins despite root rot occurrence was resulted by the collection of soybean seeds for mycotoxins analysis, while Fusarium presence was observed only on roots. It confirmed that despite plant colonization by fungi, mycotoxins are secreted only in parts of their occurrence and do not penetrate to other organs.

There was determined that some proteins (DefenseRelated; DR) have defense role against biotic stress (Souza et al., 2017), thus higher FAA concentration in our study is probably related with greater biosynthesis of defense proteins from FAA during root rot development in soybean seedlings. Moreover, higher fractions of arginine, tryptophan and aspartic acid testify to the biosynthesis of antimicrobial peptides (Mishra and Wang, 2012). Interestingly, lower precipitations in 2018-2019 caused reduction of FAA probably as the result of metabolism disorders in the environment of water deficit and their engagement in the protein against abiotic stress synthesis.

\section{Conclusion}

Selection of appropriate soybean cultivars customized to climatic conditions and resistant to Fusarium root rot is challenging aspect of pesticides reduction in agriculture. Results of the study indicated that among twelve soybean cultivars, Tanais and Isidor cultivars are at least susceptible to Fusarium root rot despite heavier rainfalls in 2020 and in this regard could be implemented to agriculture in the agroclimatic conditions of Kazakhstan. However, in aspect of yield, K-9648 cultivar was the most productive in 2018-2020. Moreover, chlorophyll fraction was comparable between soybean cultivars, however, for PhiNPQ, NPQt and LEF higher values were obtained in $4^{\text {th }}$ leaf. Furthermore, there was indicated that significant accumulation of amino acids was induced by root rot development, severity and precipitations. Thus, amino acids play the crucial role in defense proteins biosynthesis against biotic stress factors. Interestingly, despite Fusarium root rot occurrence, there were not determined mycotoxins in seeds, which indicate that they are not distributed to other organs from the place of their biosynthesis.

\section{Acknowledgment}

The paper has been written based on the results obtained from the project funded by Ministry of Science and Education of Kazakhstan Republic AP09563423: Experimental studies of fungus from Fusarium genus as causative agents of soybean root rot.

\section{Author's Contributions}

All authors equally contributed in this study.

\section{Ethics}

This article is original and contains unpublished material. The corresponding author confirms that all other authors have read and approved the manuscript and no ethical issues have been involved.

\section{References}

Abdukadirova, Z. A., Kurmanbayeva, M. S., \& Ospanbayev, Z. O. (2016). Effect of Mulch on Soybean (Glycine Max L. Merr.) at Cultivation under Drip Irrigation in the South-east of Kazakhstan. Biosciences Biotechnology Research Asia, 13(2), 51-759. doi.org/10.13005/bbra/2094

Abdulmajeed, A. M., \& Qaderi, M. M. (2019). Differential effects of environmental stressors on physiological processes and methane emissions in pea (Pisum sativum) plants at various growth stages. Plant Physiology and Biochemistry, 139, 715-723. doi.org/10.1016/j.plaphy.2019.04.030

Abugalieva, S., S. Didorenko, S. Anuarbek, L. Volkova,Y. Gerasimova,L. Sidorik and Y. Turuspekov. 2016. Assessment of soybean flowering and seed maturation time in different latitude regions of Kazakhstan. PloS one. 11(12), e0166894. doi.org/10.1371/journal.pone.0166894

Aphalo, P. J. (2017). OpenIntro Statistics, by David M. Diez, Christopher D. Barr and Mine Cetinkaya-Rundel. UV4Plants Bulletin. doi.org/10.19232/uv4pb.2016.2.90 
Assefa, Y., Bajjalieh, N., Archontoulis, S., Casteel, S., Davidson, D., Kovács, P., ... \& Ciampitti, I. A. (2018). Spatial characterization of soybean yield and quality (amino acids, oil and protein) for United States. Scientific reports, 8(1), 1-11. doi.org/10.1038/s41598-018-32895-0

Bauriegel, E., Giebel, A., \& Herppich, W. B. (2011). Hyperspectral and chlorophyll fluorescence imaging to analyse the impact of Fusarium culmorum on the photosynthetic integrity of infected wheat ears. Sensors, 11(4), 3765-3779. doi.org/10.3390/s110403765

Becklin, K. M. anderson, J. T., Gerhart, L. M., Wadgymar, S. M., Wessinger, C. A., \& Ward, J. K. (2016). Examining plant physiological responses to climate change through an evolutionary lens. Plant physiology, 172(2), 635-649. doi.org/10.1104/pp.16.00793

Chang, K. F., Hwang, S. F., Ahmed, H. U., Strelkov, S. E., Harding, M. W., Conner, R. L., ... \& Turnbull, G. D. (2017). Disease reaction to Rhizoctonia solani and yield losses in soybean. Canadian journal of plant science, 98(1), 115-124. doi.org/10.1139/cjps-2017-0053

Chang, K. F., Hwang, S. F., Conner, R. L., Ahmed, H. U., Zhou, Q., Fu, H., ... \& Gossen, B. D. (2018). Effects of Fusarium avenaceum and Rhizoctonia solani on the growth of soybean in saline soils. Canadian journal of plant science, 99(2), 128-137. doi.org/10.1139/cjps-2017-0371

Chang, X., Yan, L., Naeem, M., Khaskheli, M. I., Zhang, H., Gong, G., Zhang, M., Song, Ch., Yang, W., Liu, T., \& Chen, W. (2020). Maize/Soybean relay strip intercropping reduces the occurrence of Fusarium root rot and changes the diversity of the pathogenic fusarium species. Pathogens. 9(3), 211. doi.org/10.3390/pathogens9030211

Chilvers, M. (2019). Risk prediction tools and the interaction of soybean sudden death syndrome and soybean cyst nematode. Crops and Soils. 52 (4), 18-19. doi.org/10.2134/cs2019.52.0402

Critchley, C. (1998). Photoinhibition. Photosynthesis: A comprehensive treatise.

https://ci.nii.ac.jp/naid/10019850214/

Cruz Jimenez, D. R., Ellis, M. L., Munkvold, G. P., \& Leandro, L. F. S. (2018). Isolate-cultivar interactions, in vitro growth and fungicide sensitivity of Fusarium oxysporum isolates causing seedling disease on soybean. Plant disease, 102(10), 1928-1937. doi.org/10.1094/PDIS-03-17-0380-RE

Dutbayev, Y., Islam, R., Haus, M. J., \& Day, B. (2020a). Impact of Fusarium infections on dry bean stomatal functions and crop physiology. Annals of Agri-Bio Research. 25 (2), 270-274.

Dutbayev, Y., Rametov, N., Tsygankov, V., Islam, R., \& Kuldubayev, N. (2020b). Linear modeling approach of physiological features of soybeans. EurAsian Journal of BioSciences, 14(2).
Dutbayev, Y., Sultanova, N., Tsygankov, V., Islam, R., \& Kuldybayev, N. A. (2020c). A comparison study of biotic factor's effect on photosynthesis processes of soybean by using multispeq device on photosynq.org platform. ARPN Journal of Engineering and Applied Sciences. 15(22), 2627-2630.

http://www.arpnjournals.org/jeas/research_papers/rp _2020/jeas_1120_8398.pdf

EC. (2017). SANTE/11813/2017. Guidance document on analytical quality control and method validation procedures for pesticides residues analysis in food and feed.

https://ec.europa.eu/food/sites/food/files/plant/docs/ pesticides_mrl_guidelines_wrkdoc_2017-11813.pdf

Fones, H. N., Fisher, M. C., \& Gurr, S. J. (2017). Emerging fungal threats to plants and animals challenge agriculture and ecosystem resilience. Microbiology spectrum, 5(2), 5-2. doi.org/10.1128/microbiolspec.FUNK-0027-2016

Gutleb, A. C., Caloni, F., Giraud, F., Cortinovis, C., Pizzo, F., Hoffmann, L., Bohn, T., \& Pasquali, M. (2015). Detection of multiple mycotoxin occurrences in soy animal feed by traditional mycological identification combined with molecular species identification. Toxicology Reports. 2, 275-279. doi.org/10.1016/j.toxrep.2015.01.006

Kalaitzandonakes, N., Kaufman, J., \& Zahringer, K. (2019). The Economics of Soybean Disease Control. CABI.

Kalaji, H. M., Schansker, G., Brestic, M., Bussotti, F., Calatayud, A., Ferroni, L., ... \& Bąba, W. (2017). Frequently asked questions about chlorophyll fluorescence, the sequel. Photosynthesis Research, 132(1), 13-66. doi.org/10.1007/s11120-016-0318-y

Kuhlgert, S., Austic, G., Zegarac, R., Osei-Bonsu, I., Hoh, D., Chilvers, M. I., ... \& Kramer, D. M. (2016). MultispeQ Beta: A tool for large-scale plant phenotyping connected to the open PhotosynQ network. Royal Society open science, 3(10), 160592. doi.org/10.1098/rsos.160592

Kuldybayev, N. M., Slyamova, A. Y., Islam, R., Tsygankov, V., \& Dutbayev, Y. B. (2020). Clustering method of important soybean physiological parameters and root rots indexes.«. Исследования, результаты, 3(87), 266-274.

Kuldybayev, N., Sultanova, N., Daugaliyeva, S., Islam, R., \& Dutbayev, Y. (2019, June). Prevalence of Fusarium equiseti for soybean root rots in Western Kazakhstan. In BOOK OF ABSTRACTS (p. 257). http://static.ohu.edu.tr/uniweb/media/portallar/utufe $\mathrm{m} /$ sayfalar/16722/50jsfddn.pdf\#page $=259$

Li, N., Zhou, Q., Chang, K. F., Yu, H., Hwang, S. F., Conner, R. L., ... \& Turnbull, G. D. (2019). Occurrence, pathogenicity and species identification of Pythium causing root rot of soybean in Alberta and Manitoba, Canada. Crop Protection, 118, 36-43. 
Matorin, D. N., Timofeev, N. P., Glinushkin, A. P., Bratkovskaja, L. B., \& Zayadan, B. K. (2018). Effect of fungal infection with bipolaris sorokiniana on photosynthetic light reactions in wheat analyzed by fluorescence spectroscopy. Moscow University Biological Sciences Bulletin, 73(4), 203-208. doi.org/10.3103/S0096392518040065

McLaren, M. R., \& Callahan, B. J. (2020). Pathogen resistance may be the principal evolutionary advantage provided by the microbiome. Philosophical Transactions of the Royal Society B, 375(1808), 20190592. doi.org/10.1098/rstb.2019.0592

Murchie, E. H., \& Lawson, T. (2013). Chlorophyll fluorescence analysis: A guide to good practice and understanding some new applications. Journal of experimental botany, 64(13), 3983-3998.3 doi.org/10.1093/jxb/ert208

Nelson, R., Wiesner-Hanks, T., Wisser, R., \& BalintKurti, P. (2018). Navigating complexity to breed disease-resistant crops. Nature Reviews Genetics, 19(1), 21-33. doi.org/10.1038/nrg.2017.82

Nyandoro, R., Chang, K. F., Hwang, S. F., Ahmed, H. U., Turnbull, G. D., \& Strelkov, S. E. (2019). Management of root rot of soybean in Alberta with fungicide seed treatments and genetic resistance. Canadian Journal of Plant Science, 99(4), 499-509. doi.org/10.1139/CJPS-2018-0266

Olšovská, M. K. M. B. K. (2001). Chlorophyll a fluorescence as a bioindicator of the plant environmental stress. Acta fytotechnica et zootechnica. Proceedings of the International Scientific Conference on the Occasion of the 55th Anniversary of the Slovak Agricultural University in Nitra. 4, 6-127.

Passari, A. K., Upadhyaya, K., Singh, G., Abdel-Azeem, A. M., Thankappan, S., Uthandi, S., ... \& Singh, B. P. (2019). Enhancement of disease resistance, growth potential and photosynthesis in tomato (Solanum lycopersicum) by inoculation with an endophytic actinobacterium, Streptomyces thermocarboxydus strain BPSAC147. PloS one, 14(7), e0219014.

Pimentel, M. F., Arnão, E., Warner, A. J., Subedi, A., Rocha, L. F., Srour, A., ... \& Fakhoury, A. M. (2020). Trichoderma isolates inhibit Fusarium virguliforme growth, reduce root rot and induce defense-related genes on soybean seedlings. Plant disease, 104(7), 1949-1959. doi.org/10.1094/PDIS-08-19-1676-RE
Raza, M. M. (2019). Modeling yield loss due to soybean sudden death syndrome at different spatial scales (Doctoral dissertation, Iowa State University).

Sjarpe, D. A., Kandel, Y. R., Chilvers, M. I., Giesler, L. J., Malvick, D. K., McCarville, M. T., ... \& Mueller, D. S. (2020). Multi-location evaluation of fluopyram seed treatment and cultivar on root infection by Fusarium virguliforme, foliar symptom development and yield of soybean. Canadian Journal of Plant Pathology, 42(2), 192-202. doi.org/10.1080/07060661.2019.1666166

Souza, T.P., R.O. Diaz andM.C. Silva-Filho. 2017. Defenserelated proteins involved in sugarcane responses to biotic stress. Genetics and Molecular Biology. 40: 360-372. doi.org/10.1590/1678-4685-gmb-2016-0057

Wang, G., \& Mishra, B. (2012). The importance of amino acid composition in natural AMPs: An evolutional, structural and functional perspective. Frontiers in immunology, 3, 221. doi.org/10.3389/fimmu.2012.00221

Wang, J., Jacobs, J. L., Roth, M. G., \& Chilvers, M. I. (2019). Temporal dynamics of Fusarium virguliforme colonization of soybean roots. Plant disease, 103(1), 19-27. doi.org/10.1094/PDIS-03-18-0384-RE

Xing, J., Li, P., Zhang, Y., Li, J., Liu, Y., Lachenbruch, B., ... \& Zhao, J. (2020). Fungal pathogens of canker disease trigger canopy dieback in poplar saplings by inducing functional failure of the phloem and cambium and carbon starvation in the xylem. Physiological and Molecular Plant Pathology, 112, 101523. doi.org/10.1016/j.pmpp.2020.101523

You, M. P., \& Barbetti, M. J. (2017). Environmental factors determine severity of Rhizoctonia dampingoff and root rot in subterranean clover. Australasian Plant Pathology, 46(4), 357-368. doi.org/10.1007/s13313-017-0495-y

Zatybekov, A., Abugalieva, S., Didorenko, S., Rsaliyev, A., \& Turuspekov, Y. (2018). GWAS of a soybean breeding collection from South East and South Kazakhstan for resistance to fungal diseases. Вавиловский журнал генетики и селекции, 22(5), 536-543. doi.org/10.18699/VJ18.392

Zhang, J.X., A.G. Xue, H.J. Zhang, A.E. Nagasawaand J.T. Tambong. 2010. Response of soybean cultivars to root rot caused by Fusarium species. Canadian Journal of Plant Science. 90 (5), 767-776. doi.org/10.4141/CJPS09133 